\title{
The impact of digitalization of the economy on the development of enterprises in the Arctic
}

\author{
Maria Plakhotnikova ${ }^{1}$, and Alexander Anisimov ${ }^{1}$, Anastasia Kulachinskaya ${ }^{2}$, Liliya Mukhametova ${ }^{3}$ \\ ${ }^{1}$ Financial University (Kursk branch), 3 Lomonosov street, Kursk, Russian Federation \\ ${ }^{2}$ Peter the Great St. Petersburg Polytechnic University, 195251, Saint-Petersburg, Russia \\ ${ }^{3}$ Kazan State Power Engineering University, str. Krasnoselskaya, 51, 420066, Kazan, Russia
}

\begin{abstract}
The peculiarities of the development of the regions belonging to the Arctic zone of the Russian Federation (AZRF) are determined by geopolitical, climatic and other factors. Currently, the issues of digital transformation of national economies are paramount for all countries. However, the existing crisis phenomena caused by the economic crisis of 2008 and the COVID-19 pandemic have made their own adjustments to this process. The current conditions require both the creation of an appropriate digital infrastructure at the federal and regional levels, and the adjustment of existing development strategies at the enterprise level. However, the benefits of the digital economy will only benefit those enterprises that can adapt their development strategy in accordance with external conditions. The purpose of the study is to assess the impact of digitalization of the economy on the development of enterprises in the Arctic, as well as to form a list of the main problems in this area and search for possible ways to solve them. As a result of the study, the authors obtained the following results: (1) identified both positive and negative factors affecting the digitalization of the Russian Arctic; (2) a profile of the directions of digitalization of the Russian Arctic was created and the priority areas of digitalization were determined; (3) it was concluded that the digitalization of national economies opens up great opportunities for the further development of enterprises. However, to achieve this goal, it is necessary to timely adjust the development strategies of enterprises, taking into account the national and regional characteristics of digitalization.
\end{abstract}

\section{Introduction}

To achieve the goals of successful economic development of the regions of the Arctic zone of the Russian Federation, it is necessary, to solve the problems of integrating elements of the digital economy into the business processes of enterprises, including those operating in the territory of the Russian Arctic. At the same time, it is necessary to highlight the specific features of the impact of digitalization on the development of significant enterprises in the regions. Researchers and specialists [1], [2] and others note that at the moment a list of the main problems of the development of enterprises of the Russian Arctic, directly or indirectly related to digitalization, has been formed. Today, it is digitalization that is considered by specialists [1-6] as one of the factors of economic development of enterprises, regions and the country as a whole. The priority areas of development specified in the Strategy of Scientific and Technological Development of the Russian Federation [3] presuppose the formation of new competitive advantages of the Russian Federation based on innovative technologies and competencies, including in the field of digitalization.

At the moment, it is obvious that the basis for the active implementation of the results of the fourth industrial revolution is the massive digitalization of industry and management. These processes directly affect the competitiveness and economic stability of the Arctic regions [4], [5]. It should be noted that programs for the digitalization of the economy at the federal level have been launched in Russia. So, for example, in the state program of the Russian Federation "Socioeconomic development of the Arctic zone of the Russian Federation" [6], it is recommended that the regions of the Russian Arctic to form an innovative infrastructure, including the "transition to advanced digital, intelligent production technologies, robotic systems, new materials and design methods, creation of systems for processing large amounts of data, machine learning and artificial intelligence" [7]. Thus, the current area of research is the creation of relevant strategies for the development of enterprises operating in the Arctic regions, considering the impact of digitalization.

\section{Digital potential of the Arctic regions of the Russia}

At the moment, there are a lot of potential areas for using digital opportunities in business development in the Russian Arctic. Ensuring their implementation is a 
prerequisite for sustainable development of the AZRF economy. In the Russian Federation, the Arctic regions occupy $18 \%$ of the territory, today they are home to 2.7 million people [8], [9]. At the same time, in recent years, economic stagnation has been observed in the Russian Arctic, which negatively affects the living standards of the population of the regions and the development of business. Therefore, first of all, it is necessary to highlight the most significant areas of increasing the competitive advantages of enterprises, which are the basis of the economy of the regions of the Russian Arctic.

The study made it possible to identify the following areas of application of digitalization in the economy of the regions of the Russian Arctic:

1) digital navigation of sea vessels;

2) smart cities;

3) coordination of housing and communal services.

However, these areas require external investment and represent the future strengths of the AZRF business representatives, the economic return from which is aimed at the long term. In this regard, at present, it is very important to pay attention to the already existing advantages of the Arctic region. For example, one of these advantages is the ability to naturally cool data centers of the largest IT-companies, both Russian and foreign. This is due to the fact that the demand for data center services is growing rapidly (Figure 1). At the same time, the instability of the current economic situation due to the COVID-19 pandemic is pushing companies to strengthen their IT-infrastructure, which positively affects the commercial data center market.

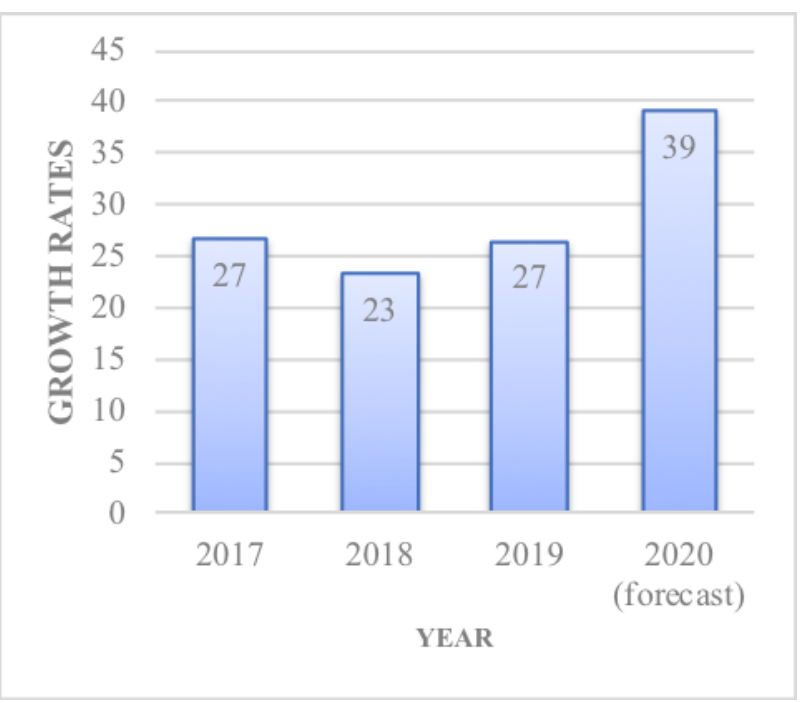

Fig. 1. Growth rate of demand for data center services (20172020), \%.

According to analysts at iKS-Consulting [10], reflected in Figure 1, the growth rate of demand for data center services by the end of 2020 will be $39 \%$, which is largely due to the consequences of the first wave of the COVID-19 pandemic. At the moment, the situation with the coronavirus creates conditions under which government bodies must prepare and adopt documents that facilitate the implementation of various teleservices (digital solutions). Research shows that, first of all, the services shown in Figure 2 will develop.

The researchers also note that the following services will receive the most intensive development in modern conditions:

1) cloud data storage;

2) backup cloud storage,

3) virtual desktops.

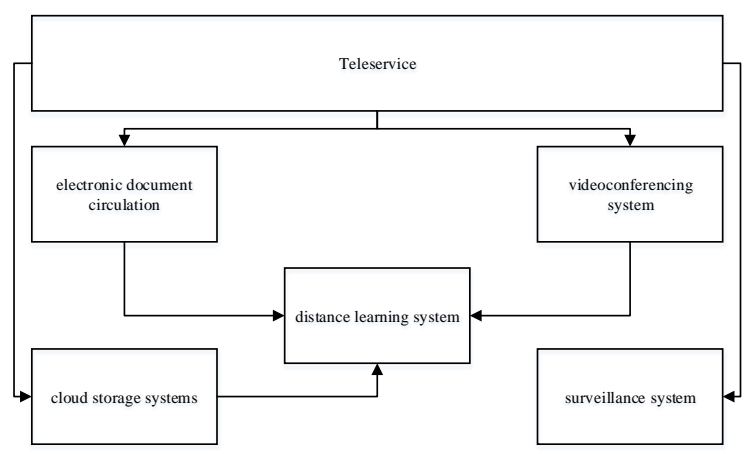

Fig. 2. Interconnections of Teleservices that are predicted to develop the most in the Arctic.

All this creates an increased demand for technologies that can reduce the cost of maintaining data centers and their energy consumption. Free cooling in the Arctic creates an additional competitive advantage in the development of this promising market. In turn, this will stimulate the development of other industries in the Russian Arctic, such as construction, energy, which, in turn, will affect the increase in jobs in the region and improve the quality of life of the population. Studies show that the use of free cooling in the Arctic can reduce the operating costs of a data center by $30-40 \%$. Therefore, it is necessary to create conditions for eliminating barriers to the development of IT-business in the Russian Arctic, both Russian and foreign. In addition, the creation of data centers in the Arctic regions makes it possible to reduce the total energy consumption, and hence to reduce the impact on the environment [11], [12].

However, in this direction of development, there are certain problems:

1) unregulated power supply required for the maintenance of data centers:

2) the need to ensure a stable connection to the telecommunications infrastructure;

3) mobilization of qualified service personnel to the far northern regions;

4) logistic difficulties;

5) construction in permafrost conditions [13], [14].

The solution to the above problems should lie in the establishment of effective partnerships between the state and business, since only in this case projects for the development of IT-business in the Arctic will become feasible. 
Table 1. PEST-analysis of selected factors affecting the digitalization process in the Russian Arctic.

\begin{tabular}{|c|c|c|}
\hline Factor & Impact on the region & $\begin{array}{l}\text { The nature of the factor's } \\
\text { influence on the organization }\end{array}$ \\
\hline \multicolumn{3}{|c|}{ Political and legal factors $(\mathrm{P})$} \\
\hline $\begin{array}{l}\text { Lack of sufficient legislative support for } \\
\text { the digitalization of the economy, } \\
\text { including the lack of laws on the } \\
\text { digitalization of the Arctic regions (P1) }\end{array}$ & $\begin{array}{l}\text { It leads to the destabilization of the digital } \\
\text { economy, a decrease in the rate of digitalization of } \\
\text { the region, the closure of access to foreign markets, } \\
\text { and the deterioration of the terms of trade. }\end{array}$ & - (negative) \\
\hline $\begin{array}{l}\text { Sanctions imposed against Russia by } \\
\text { some countries (P2) }\end{array}$ & $\begin{array}{l}\text { The sanctions provide for restrictions on financing, } \\
\text { as well as works, goods and services that can be } \\
\text { used by certain individuals on the territory of the } \\
\text { Russian Federation [17]. }\end{array}$ & - (negative) \\
\hline $\begin{array}{l}\text { High importance of the state's actions for } \\
\text { the development of the Arctic (P3) }\end{array}$ & $\begin{array}{l}\text { The state's attention to the region's problems } \\
\text { increases its competitive advantages }\end{array}$ & + (positive) \\
\hline \multicolumn{3}{|c|}{ Economic factors $(\mathrm{E})$} \\
\hline $\begin{array}{l}\text { High cost of satellite Internet connection } \\
\text { (E1) }\end{array}$ & $\begin{array}{l}\text { Limits and reduces the profitability of the region's } \\
\text { business as a whole }\end{array}$ & - (negative) \\
\hline $\begin{array}{l}\text { High demand for data center services of } \\
\text { it companies (E2) }\end{array}$ & $\begin{array}{l}\text { Overall positive impact on the state of the region, } \\
\text { increasing the profitability of its enterprises (it } \\
\text { industry, construction). }\end{array}$ & + (positive) \\
\hline $\begin{array}{l}\text { Growing demand for digital navigation } \\
\text { of marine vessels (E3) }\end{array}$ & Opportunity to develop it business in the region & + (positive) \\
\hline $\begin{array}{l}\text { Stagnation of the economy as a whole } \\
\text { (E4) }\end{array}$ & $\begin{array}{l}\text { Decrease in the level of actual salary, deterioration } \\
\text { of life }\end{array}$ & - (negative) \\
\hline \multicolumn{3}{|c|}{ Socio-cultural factors (S) } \\
\hline $\begin{array}{l}\text { The need to develop digital } \\
\text { infrastructure to reduce the risk of a } \\
\text { pandemic COVID-19 (S1) }\end{array}$ & $\begin{array}{l}\text { In this context, this factor encourages the } \\
\text { development of it technologies in the region }\end{array}$ & + (positive) \\
\hline $\begin{array}{l}\text { Population outflow from the Russian } \\
\text { Arctic (S2) }\end{array}$ & $\begin{array}{l}\text { Lack of qualified personnel for business } \\
\text { development in the region }\end{array}$ & - (negative) \\
\hline \multicolumn{3}{|c|}{ Technological factors $(\mathrm{T})$} \\
\hline $\begin{array}{l}\text { Digital inequality in the Russian Arctic } \\
\text { regions (T1) }\end{array}$ & $\begin{array}{l}\text { Creates barriers to the normal development of } \\
\text { interregional commercial relations }\end{array}$ & -(negative) \\
\hline $\begin{array}{l}\text { Uneven fiber coverage of different } \\
\text { territories in the region (T2) }\end{array}$ & $\begin{array}{l}\text { Increases the cost of communication in the region, } \\
\text { which limits business opportunities and reduces the } \\
\text { quality of life of the population }\end{array}$ & -(negative) \\
\hline
\end{tabular}

\section{Strategic analysis of the enterprises of the Arctic, considering the digitalization}

As a result of the study, we have identified the following external factors directly or indirectly related to the digitalization of the economy and affecting the development of enterprises in the Russian Arctic:

1) digital inequality of the regions of the Russian Arctic;

2) uneven optical fiber coverage of different territories in the region;

3) high cost of satellite internet connection;

4) the lack of sufficient legislative support for the digitalization of the economy, including the absence of laws on the digitalization of the Arctic regions;

5) pandemic COVID-19 (contributes to the development of IT technologies);

6) high demand for services of data-centres of IT companies;

7) growing demand for digital navigation of sea vessels;
8) the high importance of state actions for the development of the Arctic;

9) stagnation of the economy as a whole and outflow of the population from the Russian Arctic;

10) logistic and climatic features.

Considering all these factors, it can be concluded that the digitalization of the AZRF is somewhat behind the digitalization of Russia as a whole [15], [16].

In the study, we carried out a PEST-analysis (Political, Economic, Social and Technological-analysis) of the influence of the indicated external factors on the digitalization process in the Russian Arctic. The results of this analysis are presented in tables 1 and 2 . 
Table 2. Expert estimates of the probability of changes in factors in the five-year perspective and integral estimates.

\begin{tabular}{|c|c|c|c|c|c|c|c|}
\hline \multirow{2}{*}{$\begin{array}{l}\text { Factor } \\
\text { s by } \\
\text { segme } \\
\text { nt }\end{array}$} & \multicolumn{4}{|c|}{$\begin{array}{l}\text { Individual expert } \\
\text { assessments of the } \\
\text { probability of } \\
\text { changing factors }\end{array}$} & \multirow{2}{*}{$\begin{array}{l}\text { Average } \\
\text { estimate } \\
\mathrm{s} \text { of the } \\
\text { probabili } \\
\text { ty of } \\
\text { changing } \\
\text { factors } \\
\text { (Bi) }\end{array}$} & \multirow[t]{2}{*}{$\begin{array}{l}\text { Weighti } \\
\text { ng } \\
\text { factor } \\
\text { (Vi) }\end{array}$} & \multirow{2}{*}{$\begin{array}{l}\text { Integral } \\
\text { weight } \\
\text { ed } \\
\text { average } \\
\text { estimat } \\
\text { es (Si) }\end{array}$} \\
\hline & $\begin{array}{l}\text { B } \\
1\end{array}$ & $\begin{array}{l}\text { B } \\
2\end{array}$ & $\begin{array}{l}\text { B } \\
3\end{array}$ & $\begin{array}{l}\text { B } \\
4\end{array}$ & & & \\
\hline P1 & 3 & 3 & 2 & 3 & 2.75 & 0.06 & -0.18 \\
\hline $\mathrm{P} 2$ & 4 & 3 & 4 & 2 & 3.25 & 0.08 & -0.25 \\
\hline P3 & 4 & 4 & 2 & 5 & 4.50 & 0.11 & 0.48 \\
\hline E1 & 4 & 5 & & 5 & 4.50 & 0.11 & -0.48 \\
\hline E2 & 4 & 4 & 3 & 3 & 3.50 & 0.08 & 0.29 \\
\hline E3 & 5 & 4 & 5 & 3 & 4.25 & 0.10 & 0.43 \\
\hline E4 & 4 & 4 & 4 & 4 & 4.00 & 0.09 & -0.38 \\
\hline S1 & 4 & 3 & 2 & 2 & 2.75 & 0.06 & 0.18 \\
\hline S2 & 5 & 4 & 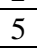 & 5 & 4.75 & 0.11 & -0.53 \\
\hline T1 & 2 & 5 & 4 & 3 & 3.50 & 0.08 & -0.29 \\
\hline $\mathrm{T} 2$ & 5 & 5 & 4 & 5 & 4.75 & 0.11 & -0.53 \\
\hline & & & & & 42.50 & 100 & \\
\hline
\end{tabular}

Based on the data obtained as a result of the PESTanalysis of the selected factors, we concluded that the state's attention to the problems of the region has the greatest positive influence from political factors. Therefore, thoughtful and coordinated actions are needed to digitalize the region's economy, both on the part of state corporations and on the part of state bodies, including in a legislative manner. An economic factor such as the high cost of satellite Internet communications has a very strong negative impact. This severely limits the development of business and social infrastructure in the Arctic regions. In conjunction with this factor, a factor also has a strong negative impact - uneven fiber coverage of different territories in the region. This factor also causes stagnation in some types of entrepreneurial activity. In addition, the outflow of the population from the Russian Arctic also has a significant impact.

To assess the directions of the impact of digitalization of the economy on enterprises in the Arctic, based on the data in Table 3, we built a profile of the directions of digitalization of the AZRF (Figure 3).
Table 3. Data to build the profile of the areas of digitalization of the Arctic.

\begin{tabular}{|c|c|c|c|c|c|}
\hline $\begin{array}{l}\text { Directions of } \\
\text { the impact of } \\
\text { digitalization } \\
\text { of the } \\
\text { economy on } \\
\text { enterprises in } \\
\text { the Arctic }\end{array}$ & $\begin{array}{c}1 . \\
\text { imple } \\
\text { mentati } \\
\text { on cost }\end{array}$ & $\begin{array}{c}2 . \\
\text { the } \\
\text { abse } \\
\text { nce } \\
\text { of } \\
\text { barri } \\
\text { ers }\end{array}$ & $\begin{array}{l}3 . \\
\text { level } \\
\text { of } \\
\text { resista } \\
\text { nce to } \\
\text { chang } \\
\text { es }\end{array}$ & $\begin{array}{l}4 . \\
\text { power } \\
\text { of } \\
\text { influe } \\
\text { nce } \\
\text { on } \\
\text { qualit } \\
\text { y of } \\
\text { life }\end{array}$ & $\begin{array}{c}5 . \\
\text { power } \\
\text { of } \\
\text { influenc } \\
\text { e on } \\
\text { business } \\
\text { develop } \\
\text { ment in } \\
\text { the } \\
\text { region }\end{array}$ \\
\hline $\begin{array}{l}\text { 1. Reducing } \\
\text { the use of } \\
\text { expensive } \\
\text { satellite } \\
\text { communicati } \\
\text { ons by } \\
\text { increasing the } \\
\text { area of fiber } \\
\text { coverage }\end{array}$ & 4 & 5 & 4 & 3 & 4 \\
\hline $\begin{array}{l}\text { 2. Addressing } \\
\text { the digital } \\
\text { divide in the } \\
\text { Arctic regions }\end{array}$ & 3 & 5 & 5 & 3 & 5 \\
\hline $\begin{array}{l}\text { 3. Patronage } \\
\text { of data } \\
\text { centers of it } \\
\text { companies }\end{array}$ & 4 & 3 & 4 & 3 & 4 \\
\hline $\begin{array}{l}4 . \\
\text { Introduction } \\
\text { of a single } \\
\text { digital } \\
\text { platform for } \\
\text { coordinating } \\
\text { the } \\
\text { transformatio } \\
n \text { of the } \\
\text { Arctic } \\
\text { economy }\end{array}$ & 3 & 3 & 3 & 4 & 4 \\
\hline
\end{tabular}




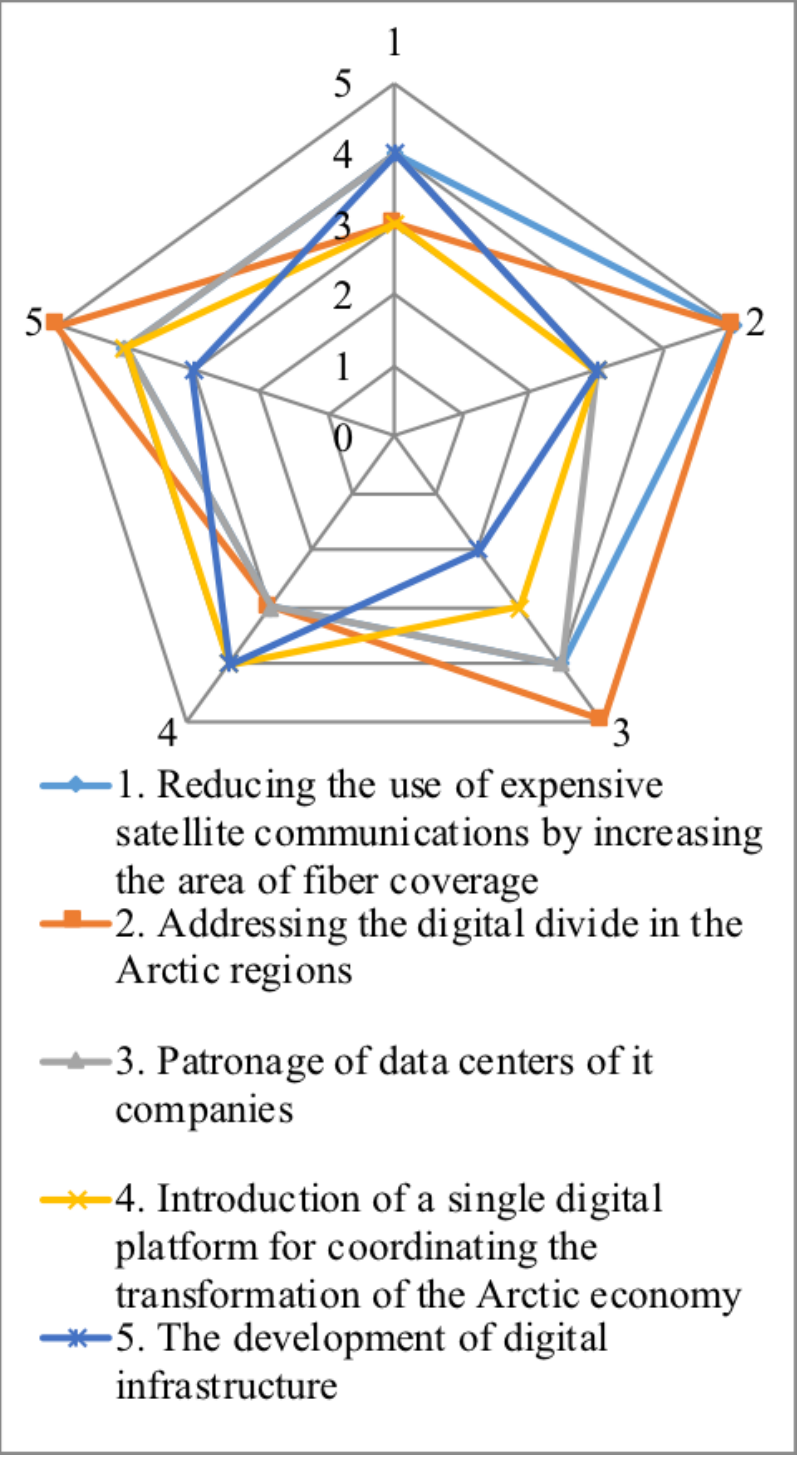

Fig. 3. Profile for evaluating the directions of digitalization of the Arctic.

As can be seen from Figure 3, the largest area is occupied by the direction "Eliminating the digital inequality of the Arctic regions", as well as "Construction of data centres for IT-companies." Therefore, these are the most important areas on which it is necessary to concentrate efforts for the development of entrepreneurial activity in the Russian Arctic.

To implement these areas, in our opinion, coordinated actions of the three main participants in the digitalization process are needed: (1) regional representatives of certain Arctic regions, (2) state corporations such as Rostelecom, Rosatom, Rostec and (3) representatives private business operating in the Russian Arctic. At the moment, there is a fragmentation of interests in the digitalization of the Russian Arctic. Enterprises and even entire industries are working on individual digitalization projects, stopping their implementation almost halfway through due to a lack of financial and labour resources. To improve the effectiveness of the relationship of the listed participants, it is necessary to combine the efforts of all groups of participants involved in the implementation of digital projects.

At the same time, the leading (unifying) role in the digitalization of the AZRF is played by the state, through the formation of the state program "Socio-economic development of the Arctic zone of the Russian Federation" [6]. In turn, the creation of relevant strategies for the development of enterprises operating in the Arctic regions, considering the impact of the digitalization program, is paramount.

\section{Conclusions}

Thus, the topic of digitalization of the Russian Arctic is multifaceted and can be viewed from different angles. The digital economy opens up great opportunities for the development of the interests of all participants in digitalization in the Russian Arctic. In the article, we identified both positive and negative factors affecting the digitalization of the Russian Arctic. Having built, on the basis of the available data, a profile of the directions of digitalization of the Russian Arctic, the priority areas for implementation were identified: "Eliminating the digital inequality of the Arctic regions" and "Construction of data-centres for IT-companies." The implementation of the identified priority areas is impossible without coordinated interaction of all interested groups: (1) regional representatives of the Arctic regions, (2) state corporations and (3) private business. Each of the groups has its own benefits from digitalization, however, without the main player, which is the state, it will be quite problematic to obtain these benefits. In addition, it should be emphasized that in order to turn the opportunities available to enterprises in the Russian Arctic into competitive advantages, effective strategies for the development of enterprises are needed, considering the peculiarities of digitalization in the regions of the Russian Arctic.

\section{References}

1. N.I. Petrova, A.V. Fedorova, N.N. Petrova, N.N. Alekseeva, IJSCM, 8(6), 999, (2019)

2. K.L. Jones, PIAC (IAC 2019-October)

3. I.M. Zaychenko, A.V. Kozlov, A.M. Smirnova, 5049 (Proceedings of the 33rd International Business Information Management Association Conference, IBIMA 2019: Education Excellence and Innovation Management through Vision 2020)

4. V. Zharov, 302(1) (IOP Conference Series: Earth and Environmental Science, 2019)

5. D. O. Eliseev, Yu. V. Naumova, PKRC RAS, 3, 5, (2015)

6. G. F. Detter, I. L. Tukkel, I, 11(241), 31 (2018)

7. A. G. Kashin, I. F. Kefeli, S. A. Malmberg, BMU, 4, 24, (2018)

8. I. L. Tukkel, N. E. Egorov,G. F. Detter, G. S. Kovrov, STBSPSPU. E., 4, 60, (2017)

9. V. S. Selin, PTD, 5(85), (2016) 
10. N. S. Baranov, SL, 3(49), 297, (2014)

11. V. V. Fauzer, A. V. Smirnov, AEE, 3(31), 3, (2018)

12. A. V. Kozlov, REM, 2(58)

13. T. V. Alexandrova, EB: T\&P, 8, 9, (2019)

14. O. Y. Krasulina, REM, 4 (48), (2016)

15. N. S. Kartamysheva, YS, 13 (93), 333 (2015)

16. N. I. Komkov, V. S. Selin, V. A. Zuckerman, PF, 1, 41 (2017)

17. V. S. Selin, V. A. Zuckerman, MID, 4 (6), 43, (2015)

18. N. I. Komkov, V. S. Selin, V. A. Zuckerman, PF, 1, 42 (2017)

19. A. V. Golik, YS, 45 (283), 280 (2019)

20. A. V. Golik, YS, 45 (283), 281 (2019). 